\title{
INQUÉRITO CIVIL: QUEM DEVE PRESIDIR - DELEGADO DE POLÍCIA OU MINISTÉRIO PÚBLICO?
}

\section{Leonardo Silva Castellani De Carvalho' Ilka Ramos ${ }^{2}$ Mauricio Martins Alves ${ }^{3}$}

Resumo - O presente artigo propõe uma discussão acerca da possibilidade do Delegado de Polícia presidir o Inquérito Civil. O Projeto de Lei 6.745, de 29 de março de 2006, preconiza alterações e inserções na Lei no 7.347 de 24 de julho de 1985 a qual trata da Ação Civil Pública, bem como do Inquérito Civil. O Projeto de Lei propõe

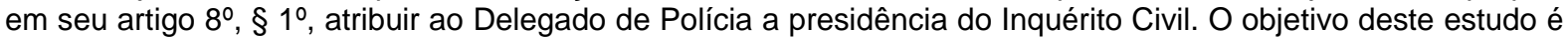
analisar essa atribuição estendida ao Delegado de Polícia, bem como seus reflexos frente ao sistema procedimental. Utilizou-se como metodologia a pesquisa bibliográfica, análise de doutrina, priorizando o Projeto de Lei e a Lei a ser alterada. Como resultados verificou-se que apesar de o Projeto ter o escopo de dar maior segurança jurídica ao processo da Ação Civil proposta pelo Ministério Público, acarretou um acúmulo de atribuições ao Delegado de Polícia, gerando uma burocratização desnecessária, condições estas já atendidas na autonomia e competência o Ministério Público.

Palavras-chave: Inquérito civil; Ministério Público; Delegado; PL 6745/06; Ação Civil.

\footnotetext{
${ }^{1}$ Direito/Universidade do Vale do Paraíba, Brasil. E-mail: leonardocastellani@outlook.com.

${ }^{2}$ Direito/Universidade do Vale do Paraíba, Brasil. E-mail: ilka@univap.br.

${ }^{3}$ Direito/Universidade do Vale do Paraíba, Brasil. E-mail: mmalves@univap.br.
} 